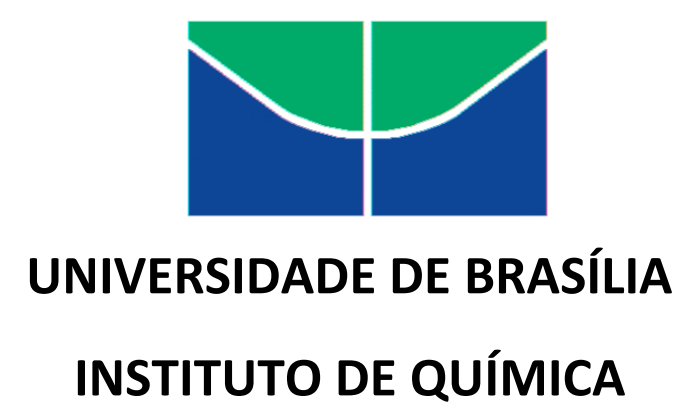

Daniélli Dotto Marsico Granja

\title{
A ESCOLA NO PROCESSO DE RESSOCIALIZAÇÃO DO ADOLESCENTE EM CUMPRIMENTO DE MEDIDA PRIVATIVA DE LIBERDADE NO DF: UMA REFLEXÃO
}

TRABALHO DE CONCLUSÃO DE CURSO

Brasília - DF

$10 / 2019$ 


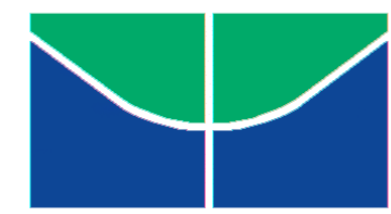

UNIVERSIDADE DE BRASÍLIA

INSTITUTO DE QUÍMICA

DANIÉLLI DOTTO MARSICO GRANJA

\section{A ESCOLA NO PROCESSO DE RESSOCIALIZAÇÃO DO ADOLESCENTE EM CUMPRIMENTO DE MEDIDA PRIVATIVA DE LIBERDADE NO DF: UMA REFLEXÃO}

Trabalho de Conclusão de Curso em Ensino de Química apresentada ao Instituto de Química da Universidade de Brasília, como requisito parcial para a obtenção do título de Licenciada em Química.

Orientador: Gerson de Souza Mól 


\section{Agradecimentos}

Gostaria de expor meu profundo sentimento de gratidão primeiramente ao meu Deus que, diante de todos os momentos de dificuldade, manteve Sua mão estendida para mim, e com Sua maravilhosa graça me deu o discernimento necessário para sair vitoriosa.

Aos meus pais, Oscar e Alessandra, por todo o sacrifício que fizeram para me proporcionar uma vida confortável, repleta de amor e de valores fundamentais. Obrigada por toda atenção destinada a mim, por sempre acreditarem no meu potencial e no meu sucesso. Sem o seu apoio eu nunca teria concluído essa fase da minha vida.

Aos meus irmãos, Franciélli e Oscar, que mesmo com todas as nossas diferenças, sempre me incentivaram e me encheram de amor. Obrigada pela confiança durante todo o percurso e em meio a tantos tropeços, me ajudaram a levantar.

A minha amada filha, Ana Lara, por nunca ter chorado quando a mamãe precisou ir para universidade, pelo seu sorriso que contagia, pelo abraço amoroso e sincero ao entrar em casa, por compreender quando a mamãe não podia brincar pois precisava estudar. Obrigada por ser minha luz, meu refúgio, meu porto seguro.

Ao meu digníssimo esposo, Thiago, que sempre foi tão compreensível nos meus momentos de ausência, nervosismo, angustia e outros que somente a graduação proporciona para uma universitária. Pelo seu companheirismo nas madrugadas de estudos e elaboração de trabalhos, eu te agradeço. Obrigada por todo o incentivo e calmaria ao dizer "vai dar tudo certo". Meu amor eterno entrego a ti.

A minha segunda mãe, lane, que auxiliou na minha criação e, hoje em dia, na criação da minha filha, obrigada pelas noites mal dormidas, por todo o carinho e constantes palavras que me edificam.

Agradeço também as minhas amigas, que se fizeram minha família aqui em Brasília, pela presença nas situações complicadas, pelas noites sem dormir em que estudamos juntas, pelo apoio recíproco. Pelo ombro disponível quando tudo parecia 
desmoronar e pelas gargalhadas quando tudo se acertava. Obrigada por nunca desistirem de mim. Vocês têm a minha admiração.

Sou eternamente grata ao meu orientador, Gerson, por compartilhar seus conhecimentos e experiências comigo, por todo o suporte durante a minha graduação, pela disponibilidade e atenção direcionadas a mim quando precisei. Por acreditar em meu sonho e apostar na minha vitória quando muitos não o fizeram. Pela oportunidade de trabalhar com você, eu agradeço.

Em geral, agradeço a todos os docentes que participaram da minha vida durante esses 5 anos de UnB. Em especial aos professores Eduardo e Marly que muito me auxiliaram e me instruíram quando a eles eu recorria, vocês são exemplos de professores. 


\section{Sumário}

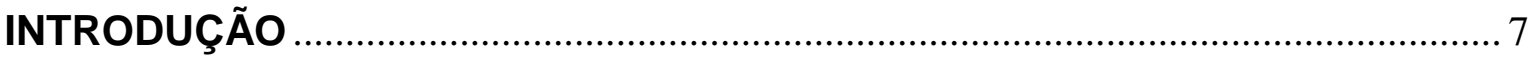

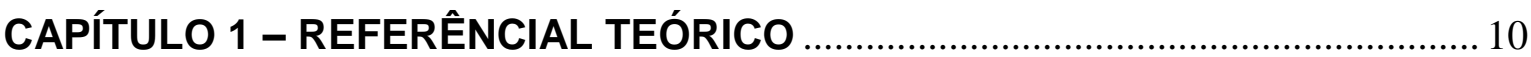

1.1. Conhecendo os adolescentes em cumprimento de medida socioeducativa privativa de liberdade no DF................................................... 10

1.2. Marco Legal da Educação no Brasil .......................................................... 12

1.3. A medida socioeducativa privativa de liberdade e o ECA....................... 15

1.5. Processo de Escolarização na Socioeducação: Escola ........................... 17

1.6. Processo de Escolarização na Socioeducação: Professor e o ensinoaprendizagem

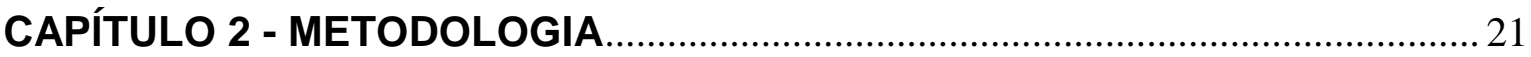

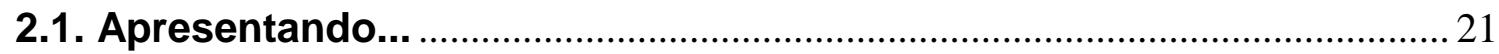

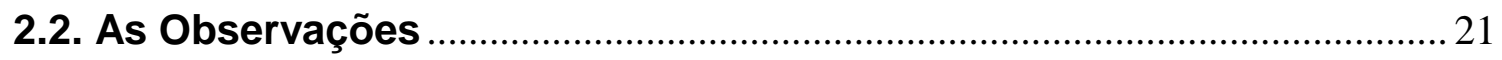

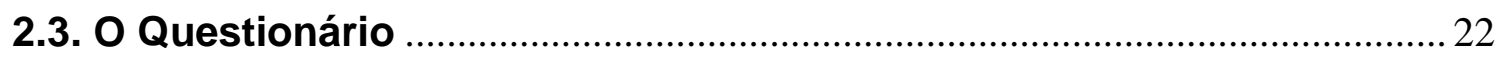

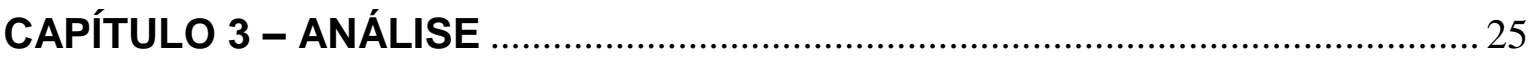

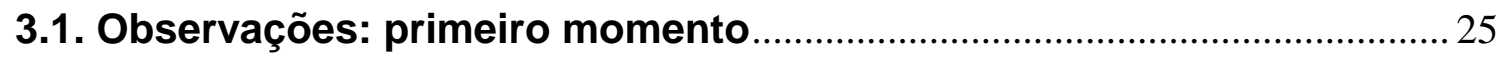

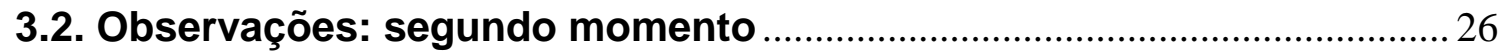

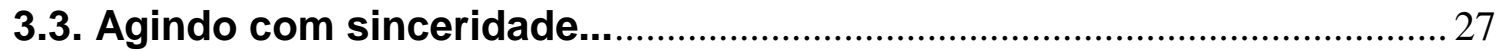

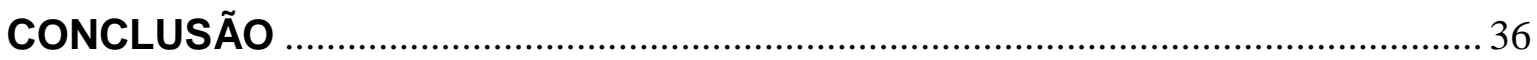

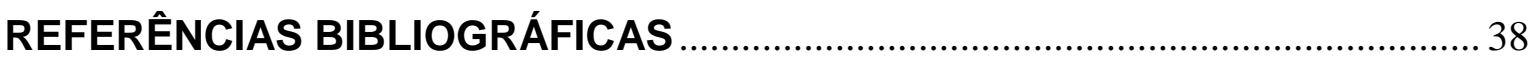

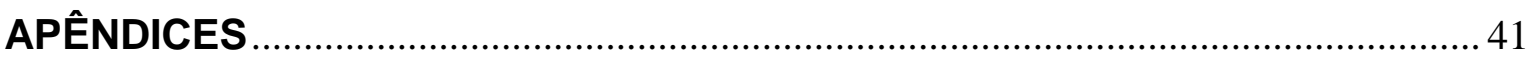

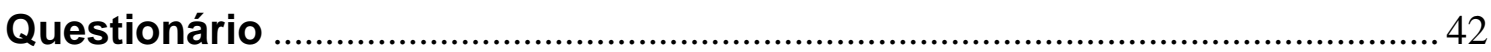

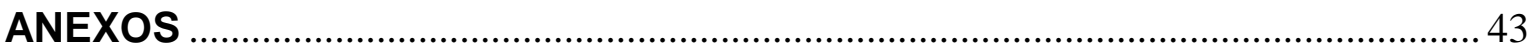




\section{RESUMO}

Esse trabalho busca incentivar uma reflexão por parte dos leitores e pesquisadores a respeito do papel fundamental da Escola dentro de uma Unidade de Internação do Distrito Federal. Essa ponderação é fomentada a partir dos relatos feitos por socioeducandos que responderam ao questionário elaborado pela autora e pelas observações feitas pela mesma durante o desenvolvimento deste trabalho. No trabalho apresentamos um pouco sobre nossa visão a respeito do ensino escolar formal nesse contexto que vem a ser tão peculiar devido às características dos socioeducandos, que diversas vezes os impedem de frequentar a escola comum, sendo defendida por uns e criticada por outros. No entanto, cabe destacar que esse é um direito constitucional desses e de todos os adolescentes brasileiros. A partir de nossas observações e estudos, percebemos que a prática docente nesse contexto é de suma importância para que a ressocialização dos jovens em cumprimento de medida socioeducativa privativa de liberdade seja alcançada, ou seja, que os mesmos saiam preparados para a cidadania e sejam reconhecidos como indivíduos com direitos e deveres.

Palavras-chave: Socioeducação; Restrição de liberdade; Ressocialização. 


\section{INTRODUÇÃO}

Como segunda filha de três irmãos aprendi a, desde pequena, me virar sozinha, pois a atenção era sempre dividida por três. Nasci em Manaus-AM, mas por ser filha de militar não cresci na minha cidade natal. Fui praticamente criada no estado do Rio de Janeiro-RJ, no qual tive o prazer de morar durante toda a infância e adolescência. Cursei o Ensino Fundamental Il e o Ensino Médio no Colégio Militar do Rio de Janeiro (CMRJ) onde, em decorrência do seu sistema rígido de ensino, aprendi valores, a ser independente em diversos aspectos e fui capaz de ingressar em uma Universidade publica por meio do vestibular (ENEM) e estar onde estou hoje: formando em um curso de Licenciatura em Química.

Ingressei na UnB no $2^{\circ}$ semestre do ano de 2014, por transferência obrigatória, oriunda da UFAM. Durante a graduação trabalhei ministrando aulas em um Reforço Escolar, durante 1 ano. Posteriormente, tive a honra de atuar como Educadora Social Voluntária no Centro de Ensino Fundamental № 01 do Cruzeiro (CEF 01 do Cruzeiro) também no período de 1 ano, e em outro momento do curso, retornei como Educadora no Centro de Ensino Médio Integral do Cruzeiro (CEMIC) por mais 6 meses. Tive a oportunidade de participar do Programa de Iniciação à Docência - PIBID, no qual permaneci por 2 anos, e atuar como monitora de Química na rede privada.

No entanto, nada é tão simples quanto parece. No meu 6으 semestre de curso na UnB, descobri que seria mãe. Então tudo mudou, menos a vontade de ser uma educadora, de ser licenciada e poder fazer a diferença na vida de muitos estudantes. Vi na licenciatura uma oportunidade de realizar objetivos de vida antigos e da melhor maneira possível, pois, além de fazer parte do processo de ensino-aprendizagem deles, posso ouvi-los, aproximá-los da Ciência e tentar mostrá-los a importância em aprender e estudar.

Portanto, segui na universidade sem realizar nenhum tipo de trancamento de matrícula, estudando de madrugada, pois era o único período do dia em que me sobrava tempo. Fui humilhada por professores que não compreenderam a minha situação e muito menos me deram o suporte que deveriam. Contudo, conjuntamente, fui acolhida por outros professores, que faziam jus a sua profissão e lutaram ao meu lado pelos meus direitos. Sou eternamente grata. 
A escolha por trabalhar um tema voltado para os adolescentes autores de atos infracionais surgiu muito antes do ingresso no curso de licenciatura. Com o tempo pude perceber que não é algo de interesse das pessoas em minha volta e da sociedade em geral, e ao realizar pesquisas, ficou evidente não ser também de conhecimento das mesmas a realidade desse contexto. Tendo em vista esse fato, optei por conhecer esses adolescentes, buscar compreendê-los, mesmo que de maneira singela, sem muito aprofundamento, e assim vivenciar o processo de ressocialização por meio da escolarização deles dentro de uma Unidade de Internação.

A medida socioeducativa de internação é a mais grave, e a mesma somente é concedida quando não há outra opção, caso contrário, o indivíduo não deve ser privado de liberdade. Além disso, essa contenção do adolescente visa a sua inserção na sociedade e, segundo Volpi, essa ação é promovida a partir iniciativas que proporcionem educação, profissionalização, saúde, lazer e outros direitos garantidos por lei. (VOLPI, 1997). Todavia, esse processo enfrenta uma variedade de desafios tendo em vista que os indivíduos autores de atos infracionais são jovens que estão em constante conflito com o mundo ao seu redor e consigo mesmo, além se serem cidadãos com histórias árduas, experiências frustrantes em diversas questões e muitas das vezes sem uma estrutura familiar fundamentada.

Embora a área de graduação seja em licenciatura em química, a preferência em produzir um trabalho com foco na socioeducação e não na química vem da carência de valorização, compreensão e até mesmo de pesquisas na área da socioeducação. É essencial que a sociedade, em especial os profissionais da área de educação, perceba a significância do papel do professor dentro de uma instituição de ensino nesse contexto.

Tendo em vista essa escassez de trabalhos com pesquisa na área da socioeducação, e a necessidade de se conhecer melhor sobre esse universo, haja vista a realidade criminal do nosso país, a obra elaborada visa um estudo voltado para a importância da Escola no processo de ressocialização dos internos da Unidade de Internação de São Sebastião - UISS, no Distrito Federal. O objetivo principal da mesma foi de, a partir de relatos dos estudantes voluntários, analisar o real papel da Escola no âmbito socioeducativo, assim como sua influência na vida desses indivíduos. 
Muitas das vezes a letra de uma melodia pode vir a ser extremamente significativa, contudo, começo esse trabalho com uma composição que muito representa a realidade dos socioeducandos, a mesma foi citada por SILVA, 2017:

Ainda me lembro aos três anos de idade $O$ meu primeiro contato com as grades

O meu primeiro dia na escola

Como eu senti vontade de ir embora

Fazia tudo que eles quisessem Acreditava em tudo que eles me dissessem

Me pediram para ter paciência

Falhei

Gritaram: - Cresça e apareça!

Cresci e apareci e não vi nada Aprendi o que era certo com a pessoa errada

Assistia ao jornal da TV

E aprendi a roubar pra vencer

Nada era como eu imaginava

Nem as pessoas que eu tanto amava

Mas e daí, se é mesmo assim

Vou ver se tiro o melhor pra mim.

[solo]

Me ajuda se eu quiser Me faz o que eu pedir Não faz o que eu fizer Mas não me deixe aqui

Ninguém me perguntou se eu estava pronto

E eu fiquei completamente tonto

Procurando descobrir a verdade

No meio das mentiras da cidade

Tentava ver o que existia de errado

Quantas crianças Deus já tinha matado.

Beberam meu sangue e não me deixam viver Tem o meu destino pronto e não me deixam escolher Vem falar de liberdade pra depois me prender

Pedem identidade pra depois me bater

Tiram todas minhas armas

Como posso me defender?

Vocês venceram essa batalha

Quanto à guerra, Vamos ver.

O Reggae

Legião Urbana 


\section{CAPÍTULO 1 - REFERÊNCIAL TEÓRICO}

\subsection{Conhecendo os adolescentes em cumprimento de medida socioeducativa privativa de liberdade no DF}

É de extrema importância que os adolescentes que estão cumprindo medida socioeducativa de internação, sejam devidamente apresentados e representados. Com esse feito é possível que isso se torne mais uma questão de análise para os envolvidos.

Uma pesquisa realizada no ano de 2012 pela Codeplan (2013), demandada pela Secretaria de Estado da Criança do Distrito Federal, buscou investigar o perfil dos adolescentes que estão em cumprimento de medida socioeducativa no DF, para melhor conhecê-los e arrecadar informações para divulgação e futuros projetos do Governo do Distrito Federal - GDF, tendo em vista a escassez de dados relacionados a esse tema. Os responsáveis entrevistaram os adolescentes, que eram efetivos até $01^{\circ}$ semestre de 2013 , de todas as unidades de cumprimento de medida socioeducativa do DF. Essa pesquisa voltada para o universo da socioeducação foi uma das maiores já feitas no Brasil. (DISTRITO FEDERAL, 2013).

De acordo com os dados recolhidos pela Codeplan (2013), a idade dos indivíduos que estão privados de liberdade varia de 13 a 20 anos, sendo em maior quantidade aqueles com 17 anos, com uma porcentagem de $31,2 \%$ como mostra a tabela 1 anexada abaixo.

Tabela 1: Número e percentual de adolescentes em medida de internação por idade e unidade de internação 


\begin{tabular}{|c|c|c|c|c|c|c|c|c|}
\hline \multirow{2}{*}{ Idade } & \multicolumn{2}{|c|}{ UIPP } & \multicolumn{2}{|c|}{ UNIRE } & \multicolumn{2}{|c|}{ UIP } & \multicolumn{2}{|c|}{ Total } \\
\hline & $\mathbf{N}$ & $\%$ & $\mathbf{N}$ & $\%$ & $\mathbf{N}$ & $\%$ & $\mathbf{N}$ & $\%$ \\
\hline 13 & 0 & 0,0 & 1 & 0,6 & 0 & 0,0 & 1 & 0,2 \\
\hline 14 & 11 & 3,8 & 3 & 1,8 & 1 & 1,2 & 15 & 2,8 \\
\hline 15 & 20 & 6,9 & 8 & 4,7 & 7 & 8,6 & 35 & 6,5 \\
\hline 16 & 39 & 13,5 & 19 & 11,2 & 19 & 23,5 & 77 & 14,3 \\
\hline 17 & 102 & 35,4 & 47 & 27,6 & 19 & 23,5 & 168 & 31,2 \\
\hline 18 & 72 & 25,0 & 52 & 30,6 & 20 & 24,7 & 144 & 26,7 \\
\hline 19 & 33 & 11,5 & 32 & 18,8 & 9 & 11,1 & 74 & 13,7 \\
\hline 20 & 10 & 3,5 & 8 & 4,7 & 6 & 7,4 & 24 & 4,5 \\
\hline Sem informação & 1 & 0,3 & 0 & 0,0 & 0 & 0,0 & 1 & 0,2 \\
\hline Total & 288 & 100,0 & 170 & 100,0 & 81 & 100,0 & 539 & 100,0 \\
\hline
\end{tabular}

Fonte: Companhia de Planejamento do Distrito Federal - CODEPLAN

No quesito local de residência, a cidade satélite Ceilândia liderou com $20,2 \%$, seguido de Samambaia, Recanto das Emas e Planaltina com 13,4\%, 8,3\% e 7,4\% respectivamente. Quanto aos dados sobre raça/cor, com base nos conceitos do IBGE, $80 \%$ declararam-se negros, $16,9 \%$ não negros e 3,2\% não tinham a informação. 35,9\% dos adolescentes informaram ter uma renda média familiar de mais de 1 a 2 salários mínimos, $23,7 \%$ de meio a 1 e $3 \%$ até meio salário mínimo, o restante declarou ter entre 2 a 3,3 a 5 e 5 a 10 salários mínimos. (DISTRITO FEDERAL, 2013).

A respeito dos atos infracionais, o roubo lidera as pesquisas com $42,1 \%$, seguido de homicídio com $14,7 \%$, tentativa de homicídio e tráfico de drogas com $8,7 \%$ e $8,3 \%$ na devida ordem. (DISTRITO FEDERAL, 2013). Entretanto, nas pesquisas de 2014, o roubo seguiu em primeiro lugar no ranking, mas o tráfico de drogas passou a ser a segunda maior causa de internação no DF. (DISTRITO FEDERAL, 2014).

Os dados relacionados a reincidência dos adolescentes são algo um tanto quanto preocupantes, pois põe em questão a eficácia do sistema socioeducativo como um todo, incluindo todos os envolvidos, da Polícia ao Poder Judiciário. Tendo em vista que $84,2 \%$ dos autores de ato infracional são reincidentes, assim como mostra a tabela 2 abaixo. (DISTRITO FEDERAL, 2013).

Tabela 2: Número e percentual de adolescentes reincidentes e não reincidentes em medida de internação, por unidade 


\begin{tabular}{|c|c|c|c|c|c|c|}
\hline \multirow{2}{*}{ Unidade } & \multicolumn{2}{|c|}{ Reincidentes } & \multicolumn{2}{|c|}{$\begin{array}{c}\text { Não } \\
\text { reincidentes }\end{array}$} & \multicolumn{2}{|c|}{ Total } \\
\hline & $\mathrm{N}$ & $\%$ & $\mathbf{N}$ & $\%$ & $\mathrm{~N}$ & $\%$ \\
\hline UIPP & 250 & 87,1 & 37 & 12,9 & 287 & 100,0 \\
\hline Unire & 141 & 82,9 & 29 & 17,1 & 170 & 100,0 \\
\hline UIP & 62 & 76,5 & 19 & 23,5 & 81 & 100,0 \\
\hline Total & 453 & 84,2 & 85 & 15,8 & 538 & 100,0 \\
\hline
\end{tabular}

Fonte: Companhia de Planejamento do Distrito Federal - CODEPLAN

No assunto escolarização, abrangendo toda a ideologia por detrás, assim como os deveres do Estado e a obrigação dos responsáveis para com os estudos dos seus dependentes, 90,9\% dos entrevistados afirmaram estarem devidamente matriculados e frequentarem a escola. 7,2\% afirmaram não estarem matriculados e apenas 1,9\% estavam matriculados, porém não frequentavam as aulas. (DISTRITO FEDERAL, 2013)

De acordo com alguns dados da pesquisa realizada pela Codeplan (2013), um grande número de adolescentes afirmou já ter sofrido algum tipo de violência. $71,8 \%$ dos internos especificaram terem sofrido violência física, e em segundo lugar ficou a violência verbal, com 10\%. Com base nas informações obtidas, a escola não é considerada um local seguro para os adolescentes, há diversos conflitos em seu interior, o que é relacionável com o percentual de violência e o fato de $82 \%$ dos jovens em cumprimento de medida socioeducativa de internação, não terem instrução e/ou ensino fundamental completo. Todavia, 93\% deles acreditam que a escola é capaz de mudar a sua vida.

A sociedade tende a generalizar os jovens autores de atos infracionais, buscando padronizá-los. Em virtude desse ato, há uma necessidade gigantesca em respeitar as particularidades de cada indivíduo no processo pedagógico, pois assim como é afirmado nas Diretrizes Pedagógicas, esses sujeitos "são jovens com histórias, estruturas psíquicas, configurações subjetivas, momentos existências e estruturas cognitivas únicas, e como tais precisam ser respeitados". (DISTRITO FEDERAL, 2014).

\subsection{Marco Legal da Educação no Brasil}

A Constituição da República Federativa do Brasil de 1988 é de suma importância para a educação do nosso país, assim como para o progresso das 
políticas sociais. A "Constituição Cidadã", maneira como ficou conhecida, segundo Woicolesco (2009), busca fazer uma modificação no paradigma da desigualdade social, tratando todas as crianças e adolescentes com similitude. Acerca da educação, a constituição de 88 garante no seu artigo 205:

Art. 205. A educação, direito de todos e dever do Estado e da família, será promovida e incentivada com a colaboração da sociedade, visando ao pleno desenvolvimento da pessoa, seu preparo para o exercício da cidadania e sua qualificação para o trabalho. (BRASIL, 2016, p. 124)

O artigo 206 da Constituição Federal - CF, inciso I, garante que um dos princípios com que o ensino deve ser ministrado é o da "igualdade de condições para o acesso e permanência na escola". (BRASIL, 2016). Complementando o artigo 205 referenciado, no artigo 208, inciso I, a CF determina que:

Art. 208. O dever do Estado com a educação será efetivado mediante a garantia de: (EC no 14/96, EC nํ5 53/2006 e EC no 59/2009)

I - educação básica obrigatória e gratuita dos 4 (quatro) aos 17 (dezessete) anos de idade, assegurada inclusive sua oferta gratuita para todos os que a ela não tiveram acesso na idade própria; (BRASIL, 2016, p. 124-125)

Posterior a CF, surge o Estatuto da Criança e do Adolescente - ECA, que é fruto da Lei № 8.069 que foi sancionada em 13 de julho de 1990, pelo ex-presidente Fernando Collor de Mello. Para o ECA, uma pessoa é considerada criança quando sua idade for inferior a doze anos, adolescente quando a idade estiver entre doze e dezoito anos, e em casos descritos pela própria lei, considera-se adolescente o indivíduo que estiver entre dezoito e vinte e um anos de idade. (BRASIL,1997). Somado ao ECA, o Estatuto da Juventude (Lei $n^{\circ} 12.852 / 2013$ ) configura como jovem aquele que estiver entre 15 e 29 anos de idade. (BRASIL, 2013). Portanto, denominações como adolescente e jovem estão presentes neste trabalho ao se fazer referência aos socioeducandos.

Motivado pela Constituição de 88, o Estatuto de 1997 tem por finalidade defender e regulamentar os direitos humanos fundamentais das crianças e dos adolescentes, visando protegê-los. Seguindo essa ideologia, o artigo 18-A do Estatuto da Criança e do Adolescente aponta que: 
Art. 18-A. A criança e o adolescente têm o direito de ser educados e cuidados sem o uso de castigo físico ou de tratamento cruel ou degradante, como formas de correção, disciplina, educação ou qualquer outro pretexto, pelos pais, pelos integrantes da família ampliada, pelos responsáveis, pelos agentes públicos executores de medidas socioeducativas ou por qualquer pessoa encarregada de cuidar deles, tratá-los, educá-los ou protegê-los. (BRASIL, 1997, p. 5)

O direito à educação é mais uma vez enfatizado no artigo 53 do ECA, assim como as obrigações do Estado para com as crianças e os adolescentes.

Art. 53. A criança e o adolescente têm direito à educação, visando ao pleno desenvolvimento de sua pessoa, preparo para o exercício da cidadania e qualificação para o trabalho, assegurando-se-lhes: I - igualdade de condições para o acesso e permanência na escola; II - direito de ser respeitado por seus educadores;

III - direito de contestar critérios avaliativos, podendo recorrer às instâncias escolares superiores;

IV - direito de organização e participação em entidades estudantis; $\checkmark$ - acesso à escola pública e gratuita próxima de sua residência. (BRASIL, 1997, p. 17)

Além da Constituição Federal de 1988 e o Estatuto da Criança e do Adolescente, em 20 de dezembro de 1996 a Lei de Diretrizes e Bases da Educação Nacional - LDB é sancionada e reafirma esse direito já garantido pela CF. De acordo com Woicolesco (2009), coadunados, esses três marcos legais asseguram o ensino público a todos, garantindo que nenhum cidadão deixará de ter acesso à educação básica por falta de vaga nas instituições de ensino.

Buscando sempre trazer a importância da escolarização em seu contexto social e de desenvolvimento do ser humano em todos os seus aspectos, o $2^{\circ}$ artigo da Lei de Diretrizes e Bases da Educação afirma:

Art. 2 A educação, dever da família e do Estado, inspirada nos princípios de liberdade e nos ideais de solidariedade humana, tem por finalidade o pleno desenvolvimento do educando, seu preparo para o exercício da cidadania e sua qualificação para o trabalho. (BRASIL, 1996, p.10)

Nos artigos 22 e 23 da Lei de 1996 é possível deparar-se de forma concreta com algumas das normatizações propostas pela LDB, tais como:

Art. 22. A educação básica tem por finalidades desenvolver o educando, assegurar-lhe a formação comum indispensável para o 
exercício da cidadania e fornecer-lhe meios para progredir no trabalho e em estudos posteriores.

Art. 23. A educação básica poderá organizar-se em séries anuais, períodos semestrais, ciclos, alternância regular de períodos de estudos, grupos não-seriados, com base na idade, na competência e em outros critérios, ou por forma diversa de organização, sempre que o interesse do processo de aprendizagem assim o recomendar. (BRASIL, 1996, p. 19)

Com base nesses artigos, é possível analisar o propósito que a LDB tem de normatizar a educação básica, trazendo em sua composição os princípios, a organização da educação e os deveres do Estado para com a educação pública. (BRASIL, 1996).

\subsection{A medida socioeducativa privativa de liberdade e o ECA}

O Estatuto da Criança e do Adolescente determina proteção integral às crianças e aos adolescentes no Brasil, assim como os seus direitos que lhes garantem uma variedade de atribuições.

Conduzindo esse fato para o contexto dos adolescentes em conflito com a lei, o Estatuto entende por ato infracional "a conduta descrita como crime ou contravenção penal. " (BRASIL, 1997). As medidas socioeducativas destinadas a cada adolescente é proporcional a gravidade do ato infracional, podendo ser elas: advertência; obrigação de reparar o dano; prestação de serviços à comunidade; inserção em regime de semi-liberdade; internação em estabelecimento educacional, e qualquer uma das previstas no art. 101, I a VI da Lei nº 8069/90 Estatuto da Criança e do Adolescente. (BRASIL, 1997).

O Estatuto defende os direitos dos adolescentes privados de liberdade, e no seu artigo 124 determina: que o mesmo deve ser tratado com respeito e dignidade; a Unidade de Internação deve ser a mais próxima da residência dos pais ou responsável; as condições das acomodações devem ser limpas e higiênicas; receber escolarização e profissionalização, assim como participar de atividades culturais e de lazer, praticar esportes e entre outras garantias previstas no artigo. (BRASIL, 1997).

A internação é a medida socioeducativa considerada mais grave. A mesma é aplicada somente quando o adolescente cometer um ato infracional que se 
encaixe nas situações impostas no artigo 122, incisos I, II e II do ECA. O Estatuto determina que caso exista outra possibilidade de medida a ser aplicada, 0 adolescente não deve cumprir a medida socioeducativa de privação de liberdade. (BRASIL, 1997). Para Volpi, a contenção dos adolescentes que são submetidos a privação de liberdade não é em si a medida socioeducativa, e sim a condição para que a medida possa ser executada. (VOLPI, 1997).

No artigo 104 do ECA (parágrafo único, art. 104 - ECA), é determinado que para o decreto da sentença de medida socioeducativa a ser cumprida, deve ser analisada a idade do infrator na data do ato infracional. (BRASIL, 1997). Por efeito de, acontece de muitos adolescentes cumprirem a sentença socioeducativa no limite ou após concluir os seus 18 anos de idade, de forma a protegê-los do encaminhamento para o sistema prisional. (DISTRITO FEDERAL, 2014). Acontecimento que pode vir a explicar um dos motivos pelo qual o índice de adolescentes/jovens com 17 anos em medida de internação, é maior do que as demais idades.

\subsection{Socioeducação no Distrito Federal}

Desde o ano de 2010, o órgão responsável pela execução das medidas socioeducativas no Distrito Federal é a Secretaria de Estado da Criança do Distrito Federal (SECriança). A mesma implementou a desativação da Unidade de Internação do Plano Piloto, que era mais conhecida como o antigo CAJE, e traçou o plano de descentralização das Unidades de Internação, fazendo com que em 2014, o DF contasse com seis Unidades de Internação e uma de Atendimento Inicial. (DISTRITO FEDERAL, 2014).

As secretarias responsáveis pela escolarização dos adolescentes em situação de cumprimento de medida socioeducativa, internação cautelar e aqueles acolhidos pelo Núcleo de Atendimento Integrado (NAI), são a Secretaria de Estado de Educação do Distrito Federal (SEEDF) e a SECriança. Em conjunto, as duas organizam rotinas e fluxos para o ofertamento de escolarização aos adolescentes e jovens em cumprimento de medidas, assim como a escolarização dos adolescentes que cumprem medidas socioeducativas no ensino regular. (DISTRITO FEDERAL, 2014). 


\subsection{Processo de Escolarização na Socioeducação: Escola}

Na realidade dos jovens de hoje, é de conhecimento geral a dificuldade que os adolescentes têm de se comunicar em situações consideradas de autoridade, tanto no contexto doméstico, quanto no contexto social. Com isso, muitas das vezes é a Escola que fica responsável por viabilizar essa relação entre o "universo doméstico" e o "universo social', sem que haja uma intervenção direta dos pais/responsáveis. (DISTRITO FEDERAL, 2014).

Muito além dessa responsabilidade, assim como está previsto pela lei, é por meio da Escola, da educação, que o socioeducando terá o seu desenvolvimento integral, visando a sua ressocialização e sua capacitação para o mercado de trabalho. Sendo assim, a Escola tem a sua função social também, na qual proporciona ensinamentos que ajudam o jovem a considerar diferentes maneiras de se relacionar com o outro, com grandes causas, ambientais e humanas, e consigo mesmo, o que intensifica as "responsabilidades educativas da Escola". (DISTRITO FEDERAL, 2014).

A escolarização na socioeducação pode ser considerada um pouco mais complexa e desafiadora quando comparada com a no ensino regular, fora das Unidades, principalmente quando se trata de jovens internos. Os adolescentes nessa fase de desenvolvimento estão com os hormônios aflorados, com conflitos internos, o que ocasiona em uma mudança notória de suas condutas.

O comportamento de um adolescente internado reúne todas essas características, mas com o adendo de que muitos deles possuem alguns transtornos por conta do histórico de uso de drogas e, por conta disso, podem vir a ser agressivos em diversas situações. Além de tudo, os adolescentes possuem uma falta de interesse grande por estarem ali contra a sua vontade, ou até mesmo por não terem algum tipo de orientação voltada para os estudos, e para complementar, os mesmos não possuem boas experiências com instituições de ensino.

Haja vista essas considerações, as Diretrizes Pedagógicas (2014) visando o sucesso no processo de escolarização desses jovens, procurou descrever as principais características que esse processo deve conter, tais como: 
"[...]; que o processo de escolarização deve considerar a diversidade dos sujeitos educativos e não apenas aguardar o aluno ideal para que possa ocorrer; que devemos ser cautelosos em relação a discursos psicopatológicos da educação e do social; que tem sido comum um caráter assistencialista da política de escolarização que desresponsabiliza o professor da condição de mediador dos conhecimentos; que precisamos reinventar a instituição escola para atender às especificidades dos sujeitos reais com os quais trabalhamos." (DISTRITO FEDERAL, 2014. p.29)

Portanto, a Escola vai além de uma instituição de ensino, na sua essência ela é transformadora, seu papel no processo da escolarização na socioeducação é de extrema importância. No entanto, é preciso que a sua função social seja completa, que haja uma formação dos adolescentes para a cidadania, que os mesmos sejam vistos como sujeitos providos de direitos e deveres, ou seja, que sejam vistos como seres capazes de aprender, com facilidades e dificuldades, assim como qualquer outro aluno do ensino regular do DF. (DISTRITO FEDERAL, 2014).

Seguindo essa linha de raciocínio, cita-se Saviani que em seu livro Escola e Democracia afirma que:

"Em suma, pela mediação da escola, acontece a passagem do saber espontâneo ao saber sistematizado, da cultura popular à cultura erudita. Cumpre assinalar, também aqui, que se trata de um movimento dialético, isto é, a ação escolar permite que se acrescentem novas determinações que enriquecem as anteriores e estas, portanto, de forma alguma são excluídas. " (SAVIANI, 2008. p. 20)

A partir deste trecho se fez possível verificar a defesa e definição da mediação da Escola no processo de escolarização, mas com uma perspectiva de aprendizagem, complementando a concepção das Diretrizes Pedagógicas.

\subsection{Processo de Escolarização na Socioeducação: Professor e o ensino- aprendizagem}

O educador colaborador na socioeducação, além de todos os seus deveres para com os seus socioeducandos, assim como cita as Diretrizes Pedagógicas, 
ele deve proporcionar uma aprendizagem que rompa com o paradigma da simples memorização de conteúdos e resoluções de exercícios sem significado para os alunos. (DISTRITO FEDERAL, 2014). Para Paulo Freire, o professor deve ser capacitado para ensinar os conteúdos de sua disciplina, mas de maneira alguma deve limitar-se em apenas ensinar aqueles conteúdos. (FREIRE, 2018).

Seguindo com Freire, ele questiona "Por que não estabelecer uma "intimidade" entre os saberes curriculares fundamentais aos alunos e a experiência social que eles têm como indivíduo?". (FREIRE, 2018). Uma das formas de quebrar o paradigma é fundamentar uma nova aprendizagem a partir do que já é de conhecimento do estudante, mas ampliando e introduzindo novos significados. (Ramos e Moraes, 2015). Afinal a construção de conhecimento darse quando os educandos atribuem significado aquilo proposto pelo professor, proporcionando uma relação entre os seus conhecimentos prévios e o que está aprendendo. (DISTRITO FEDERAL, 2014).

O professor da socioeducação não deve, em hipótese alguma, subestimar o seu aluno levando em consideração a sua atual conjuntura e realidade de ser um interno. Assim como já imposto pela lei e pelas diretrizes, todos os alunos devem receber tratamento igual, estando em situação de cumprimento de medida socioeducativa ou não. Em virtude disso, até mais do que na rede pública regular de ensino, tendo em vista a necessidade de desenvolvimento psicológico, o preparo para o mundo fora das Unidades de Internação, e a sua ressocialização, o ensino-aprendizagem dos socioeducandos precisa ter um significado, uma compreensão, caso contrário, o processo se tornará, para eles, apenas mais uma experiência fracassada em instituições de ensino.

A significação no processo de ensino-aprendizagem depende muito da relação aluno-professor e professor-aluno. Logo, o professor precisa romper com a "pedagogia magistrocêntrica", em que o mesmo é o mais importante na aula e o aluno é passivo, apenas recebe o conteúdo transmitido. Essa quebra ocasiona em uma melhora nas relações entre o professor e o aluno que são profundamente necessárias, principalmente, no âmbito da Unidade de Internação. (DISTRITO FEDERAL, 2014). De acordo com Paulo Freire, é fundamental "que professor e alunos saibam que a postura deles, do professor e dos alunos, é dialógica, aberta, 
curiosa, indagadora e não apassivada, enquanto fala ou enquanto ouve." (FREIRE, 2018).

Sendo assim, o professor é responsável pela mediação do socioeducando com o conhecimento cientifico, um dos motivos pelo qual deve haver uma boa relação e, considerando os seus conhecimentos empíricos, o mesmo deve introduzir uma aprendizagem com uma perspectiva de troca de experiências. (DISTRITO FEDERAL, 2014). Com isso, Freire (2018) disserta sobre o comportamento desse professor perante as experiências de seus alunos, assim como suas dúvidas, rebeldias e personalidade:

O professor que desrespeita a curiosidade do educando, o seu gosto estético, a sua inquietude, a sua linguagem, mais precisamente, a sua sintaxe e sua prosódia; o professor que ironiza o aluno, que minimiza, que manda que "ele se ponha em seu lugar" ao mais tênue sinal de sua rebeldia legitima, tanto quanto o professor que se exime do cumprimento de seu dever de propor limites a liberdade do aluno, que se furta ao dever de ensinar, de estar respeitosamente presente à experiência formadora do educando, transgride os princípios fundamentais éticos de nossa existência. (Freire, 2018. p. 59)

Desta forma, o professor da socioeducação assume um dos papéis de maior importância no processo de ressocialização e escolarização dos internos, pois o contato entre eles é diário. Os discursos feitos em sala de aula são feitos com liberdade de expressão, pois os alunos, principalmente quando há uma boa relação aluno-professor, conversam sobre suas aflições e erros, o que proporciona ao educador uma oportunidade de ajudá-los, aconselhá-los e instruílos, pois, muitas das vezes é isso o que lhes falta: atenção e instruções. 


\section{CAPÍTULO 2 - METODOLOGIA}

\subsection{Apresentando...}

Embora as leis e resoluções que regulamentam o sistema da socioeducação sejam de acesso a todos, poucas pessoas tem conhecimento dos deveres do Estado para com esses socioeducandos e dos direitos dos mesmos. Quando o assunto é a escolarização desses jovens, poucas são as pessoas que tem conhecimento de que há escolas dentro de Unidades de Internação - Uls, além de não saberem como funcionam e quais são os desafios e possibilidades na prática docente dentro dessas instituições. A Unidade de Internação na qual realizamos esse estudo é localizada na cidade satélite de São Sebastião - UISS, no Distrito Federal. Porém, tendo em vista que esses estabelecimentos de cumprimento de medida seguem o mesmo regulamento, houve momentos em que foi possível abranger ideias gerais do contexto socioeducativo dessas unidades existentes no Distrito Federal.

Motivações pessoais e profissionais nos levaram a querer conhecer melhor o contexto de jovens em cumprimento de medida socioeducativa privativa de liberdade. Segundo Volpi (1997) "a finalidade maior do processo educacional, inclusive daqueles privados de liberdade, deve ser a formação para cidadania". Por isso, nesse trabalho buscamos compreender melhor a importância da Escola, dentro de Uls, além da sua influência na vida desses socioeducandos, não apenas por meio de dados numéricos, mas sim por meio de relatos feitos por eles, com bases em suas experiências e opiniões pessoais.

\subsection{As Observações}

Primeiramente, foram realizadas observações no dia a dia dos professores da Unidade de Internação. Essas observações tinham como objetivo compreender melhor as estratégias usadas por esses professores, quanto as suas facilidades e dificuldades de execução, tendo em conta o contexto no qual estão inseridos e suas restrições. Não foram realizadas entrevistas com os socioeducadores. Utilizamos como dados para a compreensão do contexto, nossas observações feitas em sala de aula. Todas as informações foram anotadas em um diário de campo, para que 
nada fosse perdido e depois pudéssemos analisá-las, buscando compreendê-las fora da emoção muitas vezes presente nesse trabalho.

O propósito desse primeiro momento foi entender com uma maior profundidade, o contexto do processo de ensino-aprendizagem desses jovens. Dessa forma, acreditamos que ao analisarmos os esforços dos professores, suas escolhas metodológicas e limitações, foi possível compreendermos melhor os constantes desafios enfrentados por esses socioeducadores todos os dias, sendo também um indicador de exemplo de desenvolvimento dos alunos para os quais ensinam.

Assim, segundo Zanelli (2002), “a observação atenta dos detalhes põe o pesquisador dentro do cenário, para que possa compreender a complexidade dos ambientes psicossociais, ao mesmo tempo em que lhe permite uma interlocução mais competente". Ou seja, para que consigamos ter uma melhor compreensão desse universo da socioeducação e das nuances da escolarização desses adolescentes, é preciso que estejamos, de alguma forma, inseridos no contexto, procurando ao máximo estar atento a cada detalhe.

Em um segundo momento, as observações foram voltadas para os socioeducandos, com o intuito de conhecermos suas expectativas para com as aulas e com os professores. Fatores como interesse, comportamento em sala de aula, dificuldades e facilidades na aprendizagem, relação dos alunos com os professores e com a instituição em geral, também foram explorados.

Deste modo, o processo envolvendo as observações do contexto geral de uma Unidade de Internação, assim como a rotina dos envolvidos e suas especificidades, foi de suma importância para a ambientalização dos pesquisadores e suas reflexões.

\subsection{O Questionário}

Os socioeducandos têm pouca liberdade dentro das Unidades de Internação, e poucas são as vezes nas quais é possível encontrá-los juntos. $\mathrm{Na}$ maioria das vezes eles saem dos módulos de reclusão apenas com os agentes, geralmente dois jovens por agente. Com isso, a oportunidade mais viável de realizar esse próximo momento da proposta seria no horário de aula, pois os 
mesmos são levados para as escolas, onde há, em média, 4 ou 5 alunos por turma. Tendo em vista esse fato, primeiramente foi necessário solicitar um tempo da aula de um professor, por volta de 10 minutos, para que então pudesse dar prosseguimento a proposta.

O terceiro momento consistiu na aplicação de um questionário, com título "Agindo com sinceridade", contendo 6 perguntas:

- Qual a sua idade?

- Você tem filho(a)(s)? Se sim, quantos?

- Você estudava antes de vir para a Unidade?

- Se sim, em qual a série na qual estava matriculado?

- Você quer continuar estudando ao sair daqui?

- Qual a importância da Escola, aqui dentro da Unidade de Internação, para a sua vida?

Seguindo essa ordem, as 5 primeiras perguntas têm como objetivo conhecer melhor os socioeducandos que estão participando da pesquisa.

A última pergunta, que vem a ser discursiva, é a principal para o desenvolvimento do trabalho, pois nos possibilitou analisar as narrativas feitas pelos internos. De acordo com Nogueira (2002), os questionários abertos, ou seja, que englobam esse tipo de questão discursiva, têm como característica principal explorar todas as possíveis respostas a respeito de um item, sendo assim, foi possível coletar diversas opiniões e relatos através de um mesmo questionamento: "Qual a importância da Escola, aqui dentro da Unidade de Internação, para a sua vida?".

Esse questionário tinha como objetivo nos permitir entender o papel da Escola, dentro das Unidades de Internação, para os socioeducandos, para a vida deles dentro e fora da instituição prisional, além de ser útil para verificarmos algumas das informações da CODEPLAN (2013), como por exemplo a de que a maioria dos jovens cumprindo medida socioeducativa acredita que a escola é uma oportunidade para mudar de vida. As variáveis foram muitas pois os jovens têm entre 16 e 21 anos, com maturidades, personalidades, experiências e objetivos diferentes, e todos esses fatores influenciaram no relato de cada um.

Após as observações, já com um possível entendimento do real funcionamento da prática docente dentro das Uls, assim como o comportamento 
dos alunos durante as aulas e suas particularidades, as respostas elaboradas por esses estudantes foram interpretadas por nós, pesquisadores, conhecedores do contexto da escolarização na socioeducação e consequentemente nos permitiu compreender melhor a importância da Escola para os socioeducandos. 


\section{CAPÍTULO 3 - ANÁLISE}

\subsection{Observações: primeiro momento}

A partir das observações do dia a dia dos professores em sala de aula, na Unidade de Internação de São Sebastião, um dos aspectos percebido foi o grande esforço da parte dos mesmos em trabalhar assuntos que fossem do cotidiano dos estudantes, dessa forma, os conteúdos lecionados por eles eram ricos em contextualização. Essa informação entra em constante harmonia com a proposta de um dos referenciais utilizados nesse trabalho, o das Diretrizes Pedagógicas, que em seu corpo, aborda sobre o dever do professor em não se limitar somente em ensinar os conteúdos programados, mas fazer com que os mesmos agreguem significado para os alunos. (DISTRITO FEDERAL, 2014).

Por ser uma área de grande interesse, tendo em vista que os pesquisadores são do Ensino de Química, uma das regências que tivemos a oportunidade de prestigiar foram as aulas de química para $01^{\circ}, 2^{\circ}$ e $3^{\circ}$ ano do ensino médio. Nessas circunstâncias, a contextualização foi uma estratégia muito usada pela professora responsável, o que visivelmente favoreceu a compreensão dos socioeducandos, visto que a participação dos mesmos era constante e muito enriquecedora para o processo de ensino-aprendizagem. Sendo assim, o ensino de química, e de ciências em geral, quando contextualizado é muito mais convidativo para o aluno e simultaneamente quebra o paradigma proporcionando uma visão cientifica dos fenômenos vivenciados no dia a dia.

Um dos desafios observado de ser um professor regente em uma escola inserida em uma UI, é o fato de perdurar uma alta rotatividade de estudantes. As turmas não são constantes, pois todos os dias existem alunos sendo liberados e alunos dando entrada no sistema socioeducativo. Portanto, há uma necessidade por parte do professor de planejar suas aulas com objetivos de ensino a curto prazo, pois a probabilidade de um determinado aluno não estar presente na próxima aula é grande. Caso o educador não considere essa circunstância, há uma grande chance de o mesmo frustrar-se durante o processo.

Por conta do regime de segurança da UISS e em todo o sistema prisional, embora o professor busque por ideias inovadoras para o ensino, existem diversas restrições referentes a materiais, por exemplo. É proibida a entrada de pen drives 
em sala de aula, o que dificulta a utilização do recurso de vídeos e slides, ou a entrada com vidrarias para a realização de experimentos. Da mesma maneira, não é permitido que os alunos saiam das salas de aula com algum tipo de material escolar (lápis, caderno, borracha ou livros), ou seja, não existe a possibilidade de os estudantes realizarem atividades nos módulos, tudo deve ser iniciado e finalizado na escola, o que também contribui para a imprescindibilidade do planejamento com objetivos mais imediatos.

O papel do professor no processo de ressocialização é de suma importância, pois a convivência diária com os socioeducandos proporciona uma conexão com os internos. Durante as observações foi possível presenciar momentos em que os alunos, por se sentirem mais livres, seguros e terem uma boa relação com 0 professor, pediram conselhos e partilharam de suas angustias. Esse fato abre um portal para que o educador possa ensiná-los valores, dialogar sobre o certo e errado, buscar suprir a carência que eles têm de informações primordiais sobre a vida, pois a grande maioria não tem uma família bem estruturada. Sendo assim, mais uma vez fala-se sobre a realidade do professor não se limitar em apenas ensinar os conteúdos (FREIRE, 2018), mas que o mesmo precisa estar aberto a outros diálogos, e pronto para escutar as experiências, de um modo geral, de seus alunos.

\subsection{Observações: segundo momento}

Nesse segundo momento, conforme proposto, as observações foram mais voltadas para os socioeducandos. O aspecto que chama a atenção é o comportamento dos internos em sala de aula, pois mesmo inseridos nesse contexto prisional, com todas as circunstâncias, eles têm muito respeito para com os professores, são participativos e colaboram bastante para o bom andamento das aulas. É evidente que são adolescentes e agem como tal, portanto tem seus momentos de agitação e inquietude, porém não presenciamos nenhuma situação em que os agentes penitenciários precisaram intervir, somente o diálogo entre professor e aluno bastou.

Há internos que não estudavam antes de entrar na Unidade de Internação, em consequência disso, o grau de dificuldade dos estudantes é significativo, o que 
ocasiona em uma escolarização com um processo de ensino-aprendizagem mais lento. Portanto, o ritmo de ensino das escolas dentro das Uls é completamente diferente das escolas regulares fora dos estabelecimentos de medidas socioeducativas.

Como já falado, os internos somente circulam dentro da Unidade quando acompanhados de agentes, geralmente um agente para cada dois educandos. Uma das observações feita foi a de que em todos os dias que estivemos na UISS, aconteceu de alguns alunos chegarem depois do horário previsto para início das aulas em decorrência de atrasos por parte dos agentes penitenciários. Inclusive, em oportunidades que se teve de perguntar para eles o motivo do atraso, tivemos respostas como: "Eles (os agentes penitenciários) não queriam me tirar de lá" e "Os agentes demoraram pra me buscar".

De modo geral, os socioeducandos gostam de estarem na escola, porém, durante o tempo de convívio com os adolescentes, foi possível ouvir e fazer anotações sobre a insatisfação dos mesmos para com a Unidade e a vida lá dentro. Em uma das sextas-feiras que estivemos dentro da UISS, presenciamos duas tentativas de suicídio, o que nos fez refletir sobre a realidade desses internos a partir do momento em que a aula termina e eles retornam para os módulos. Será a escola um refúgio para esses socioeducandos?

\subsection{Agindo com sinceridade...}

O terceiro momento desse estudo consistiu na aplicação do questionário, Agindo com Sinceridade, que possibilitou aos estudantes relatarem suas experiências e opiniões em relação a importância da Escola, dentro da Unidade de Internação, para as suas vidas. Além disso, foi possível conhecer um pouco de cada um dos envolvidos. Um total de 35 socioeducandos participaram da pesquisa respondendo as 6 perguntas, todos de forma voluntária e na faixa etária de 15 a 20 anos.

De acordo com a pesquisa realizada, 33 alunos afirmaram que querem continuar os estudos após cumprirem o tempo da medida, e apenas 2 internos responderam não terem vontade de continuar estudando, o que representa apenas $5,7 \%$ dos participantes. Desses 33 alunos que desejam continuar, 17 deles 
responderam não estarem estudando antes de ingressar na Unidade, ou seja, é possível perceber que a contenção desses adolescentes viabilizou um contato com o universo escolar, mesmo que de maneira diferenciada, e promoveu uma mudança nas suas perspectivas de estudos para o futuro. Essa transformação pertence ao conjunto de objetivos da escolarização na socioeducação, e pode ser vista como um avanço no processo.

Quando indagados sobre a importância da escola na Unidade de Internação para a vida deles, assim como já era esperado, as variáveis foram muitas. Foram recolhidas respostas como a importância da escola é apenas para "passar o tempo", e que era "uma motivação para sair da vida do crime", mas acreditamos que alguns dos relatos mereciam uma exposição maior por conta da sinceridade transmitida por eles.

Apesar da linguagem pertinente nos relatos ser coloquial, as narrativas elaboradas foram totalmente compreensíveis em termos gramaticais e de concordância. Além disso, é notório que algumas das opiniões que surgiram foram bastante direcionadas para os profissionais responsáveis pela segurança da Unidade, mas, embora não fossem tão agradáveis à leitura, as mesmas descrevem a realidade dos voluntários, portanto foram mantidas uma vez que o foco da proposta são eles, os socioeducandos.

Para mais, no início de cada parágrafo referente a uma narrativa, será possível notar algumas informações pessoais do socioeducando, autor do relato, com a intenção de que os leitores compreendam melhor o contexto e o significado de suas palavras.

O estudante autor da resposta abaixo tinha 16 anos de idade e estava no $9^{\circ}$ ano do Ensino Fundamental II. Ao ser questionado sobre a escola dentro da UI, ele disse: "Pra dar aprendizado pra nois para nois sair dessa vida, e continuar estudando lá fora pra ajudar nossa família e ajudar nossa mãe, e também pra gente sair do módulo que já é um tempo que agente fica fora da tranca, a escola é um lugar de boa que agente aprende bastante."

Foto 1: Resposta retirada do questionário feito com internos na UISS 
6- Qual a importância da Escola, aqui dentro da Unidade de Internação, para a sua vida?

Pra don aprendigado pra mair pra Nole sais desea

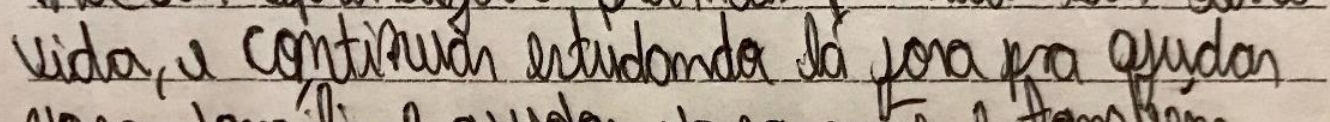

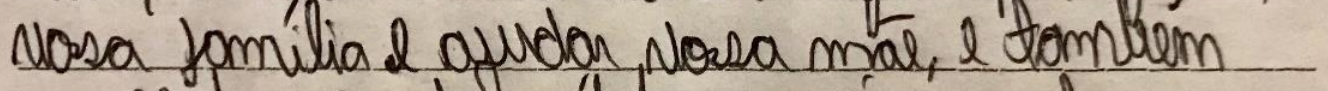
pra pente rain do módula que Jáe ulm tempre que ogente fica jora da tromea, a escola e sum dugan de dooa que agente aprende boctonte.

Fonte: a autora (2019)

A partir desse relato foi possível notar o grau de dificuldade dos socioeducandos, já citado acima, porém não é o foco principal dessa pesquisa, portanto em todos os relatos analisados não foi levado em consideração o cuidado com a escrita, mas sim as experiências e as opiniões compartilhadas. Em continuidade, foi possível perceber a preocupação do adolescente com os familiares deixados lá fora, e como o mesmo enxergava na escola uma oportunidade para mudar de vida, além de ser um momento de distração na rotina dentro do sistema.

No segundo relato, o adolescente em questão não estudava antes de entrar na UISS, mas foi um dos que respondeu desejar continuar estudando ao sair. Ele tinha 18 anos de idade e 2 filhos (as). O mesmo respondeu: "Eu acho muito bom porquê o estudo é muito importante na vida de todos para nois sair daqui e ter mais chance lá fora de emprego, para quem tem filho".

Foto 2: Resposta retirada do questionário feito com internos na UISS 
6- Qual a importância da Escola, aqui dentro da Unidade de Internação, para a sua vida?

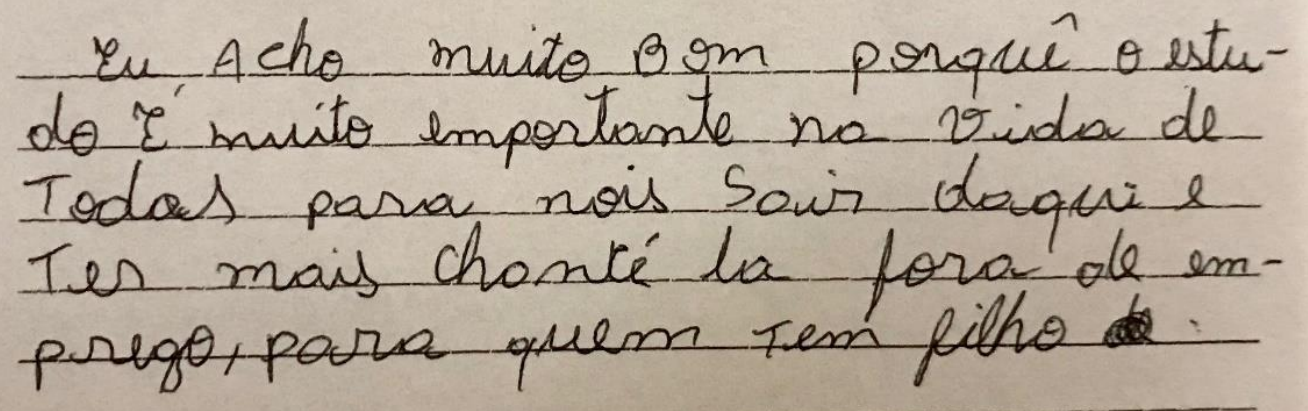

Fonte: a autora (2019)

Em diversos relatos foi possível depararmos com a associação entre estudo e possibilidade de emprego. De acordo com as Diretrizes Pedagógicas, a Escola é - caminho para o desenvolvimento, ou seja, o amadurecimento dos socioeducandos, visando sempre a sua ressocialização e capacitação para o mercado de trabalho. (DISTRITO FEDERAL, 2014). Os educandos acreditam que ao terminarem os estudos terão mais oportunidades na vida, principalmente no quesito profissional, o que para nós, educadores, é excelente pois atua como uma espécie de incentivo e resulta em um maior interesse pelos ensinamentos em sala de aula. Embora haja um certo pré-conceito da parte da sociedade em contratar indivíduos com esse tipo de histórico, é válido ressaltar a expectativa dos internos nesse aspecto, além de que a própria lei relaciona a educação com a capacitação para o mercado de trabalho, logo o que os educandos esperam não é nada além do que já está previsto.

A próxima narrativa foi de um socioeducando de 19 anos de idade que estava no $2^{\circ}$ ano do Ensino Médio. Sobre a importância da escola na vida dele, ele disse: "É muito importante pois aqui nesse lugar nois somos tratados como animais, e nois temos a nossa forma de se expressar na sala de aula, mostrando que a educação pode mudar as pessoas tanto na ignorância quanto na arogância, este lugar é muito pesado só traz mas ódio no coração, apanhamos por estar certo e 
somos punidos pela opresão, nois somos todos iguais mas parece que o direito de igualdade não existe. Obrigado pela atenção. Não somos bichos"

Foto 3: Resposta retirada do questionário feito com internos na UISS

6- Qual a importância da Escola, aqui dentro da Unidade de Internação, para a sua vida?

E'muito importante pois aqui nesse e nois temos a nossa forma de se eppresar ma sala de aula, mostran. do que a educacã pode mudar as possoas tonto ma iqnerancia quanto na orregancia, esté lugar é muito pessado só traz mas ódic no cora. cor apanhamos pos estár. certe e somos punides pela cepresar, mais somas todes iguais mas perece que Ol direito de igualodade now esiste. - Marigado somes Diches

Fonte: a autora (2019)

Nesse último relato, o estudante afirmou que, para ele, a sala de aula é um lugar de liberdade de expressão em que o mesmo se sente capaz de expressar-se e acreditava ser ouvido pelos seus professores. Entretanto, ele descreveu a Unidade de Internação como um lugar de opressão, em que eles apanhavam e eram tratados como animais, o que não está previsto na lei, muito pelo contrário, o artigo 18-A do ECA afirma que "[...] o adolescente têm o direito de ser educados e cuidados sem o uso de castigo físico ou de tratamento cruel ou degradante, [...]". (BRASIL, 1997, p.5). Todavia, o socioeducando foi capaz de separar os ambientes, UISS e Escola, e ainda disse acreditar que a educação consegue transformar as pessoas.

O relato seguinte foi de um socioeducando de 18 anos que, antes da vida na UI, estava matriculado no $9^{\circ}$ ano do Ensino Fundamental II e no período da 
32

pesquisa, o mesmo encontrava-se no Ensino Médio. Ao ser indagado sobre a importância da escola dentro da UI, o mesmo respondeu: "É importante, pois nos ajuda a evoluir nosso pensamento e a tirar nois do barraco pois é mal ficar la dentro trancado o dia todo ainda mais com uns agente areia que só quer nos atrasar e só querem ver nois na mal pois os únicos que acreditam em uma mudança de vida em nois são os professores, são os únicos pois o resto não tão nem ai pra nois, e a escola tem esse papel fundamental a nos ajudar a ter uma mudança de vida pois quero uma vida melhor terminar os estudos e a faculdade se forma em direito e ter uma vida melhor. E não somos bichos pois é o jeito que nos tratam. "

Foto 4: Resposta retirada do questionário feito com internos na UISS 6- Qual a importância da Escola, aqui dentro da Unidade de Internação, para a sua vida?

Cimportante, poir mos afuda a holuir nosse pensamento e a tirar mosis do barraco pais ena mal fucar la dentro trancado o dia todo ainda mais com uns ogente ario que so quer mos atrasar e so quesem ver nois ma mal pois as unveres que acreditarm en una mudanca de vida lm mois são os professores são os unicos pois o resto náo täo mem a papel fundamenta a nos afudon a ter una mudanca de voda pais quero unna vida miethor terminan os estudos e a facuedade se farma em duresta ter una vida melera.

\& não samon buchos preis e o fut que mos tratam

Fonte: a autora (2019) 
Mais uma vez o papel da Unidade de Internação apareceu de forma denegrida, em particular dos agentes penitenciários responsáveis pelos internos, que na visão deles só desejam o mal e querem vê-los em situação ruins. Desfrutando desse relato, é válido ressaltar que essa análise foi voltada apenas para as opiniões dos socioeducandos, sejam elas contra ou a favor do sistema. Foi agradável ver que mesmo vivenciando essas experiências, o estudante viu a escola como um caminho para mudar de vida, e mais além, viu nos professores um incentivo para ser alguém melhor. Logo, o fato do mesmo ter essa mentalidade já demonstra uma transformação, como ele mesmo narrou que a escola "nos ajuda a evoluir nosso pensamento", e essa evolução é resultado do processo de ressocialização a partir da escolarização.

Em outro relato, o socioeducando tem 19 anos, 1 filho (a), não frequentava a escola antes de adentrar na Unidade de Internação, mas almejou continuar estudando após a sua liberação. Em resposta à pergunta central do questionário tivemos: "A importância é que aprendemos muitas coisa que não aprendemos na rua e melhora nossa forma de tratar as pessoas. ".

Foto 5: Resposta retirada do questionário feito com internos na UISS

6- Qual a importância da Escola, aqui dentro da Unidade de Internação, para a sua vida?

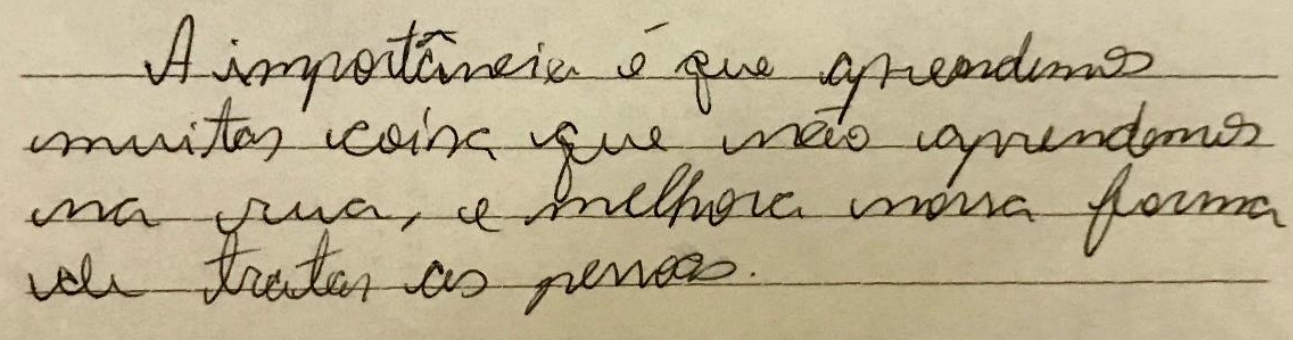

Fonte: a autora (2019)

Haja vista que um dos objetivos da escola é trazer ensinamentos de diversas áreas para os que ela frequentam, foi coerente que, como o autor não estudava antes, ele apresentou a conclusão de que na escola "aprendemos muitas coisas que não aprendemos na rua". Entretanto, a frase que mais chamou a atenção dos pesquisadores nessa exposição foi a de que a escola "melhora nossa forma de tratar as pessoas", pois corrobora com a afirmação de que um dos papeis 
fundamentais da escola é proporcionar novas maneiras de relacionamento do indivíduo consigo e com o outro. (DISTRITO FEDERAL, 2014).

A última análise, porém, não menos prestigiada, foi do texto feito por um adolescente de 17 anos, o mesmo não estava matriculado em alguma escola anteriormente a sua contenção, mas disse querer continuar os estudos ao acabar o comprimento da medida. Quanto a pergunta sobre a importância da escola na UI ele respondeu: "Bom, para min foi muito importante pois se eu não tivesse essa "força" igual tenho aqui dentro não iria concluir meus estudos e fazer uma faculdade de "Educação-Física". Aqui dentro eu tenho todo o apoio que eu sempre precisava. Sou muito grato pelos professores da Unidade de Internação. ".

Foto 6: Resposta retirada do questionário feito com internos na UISS

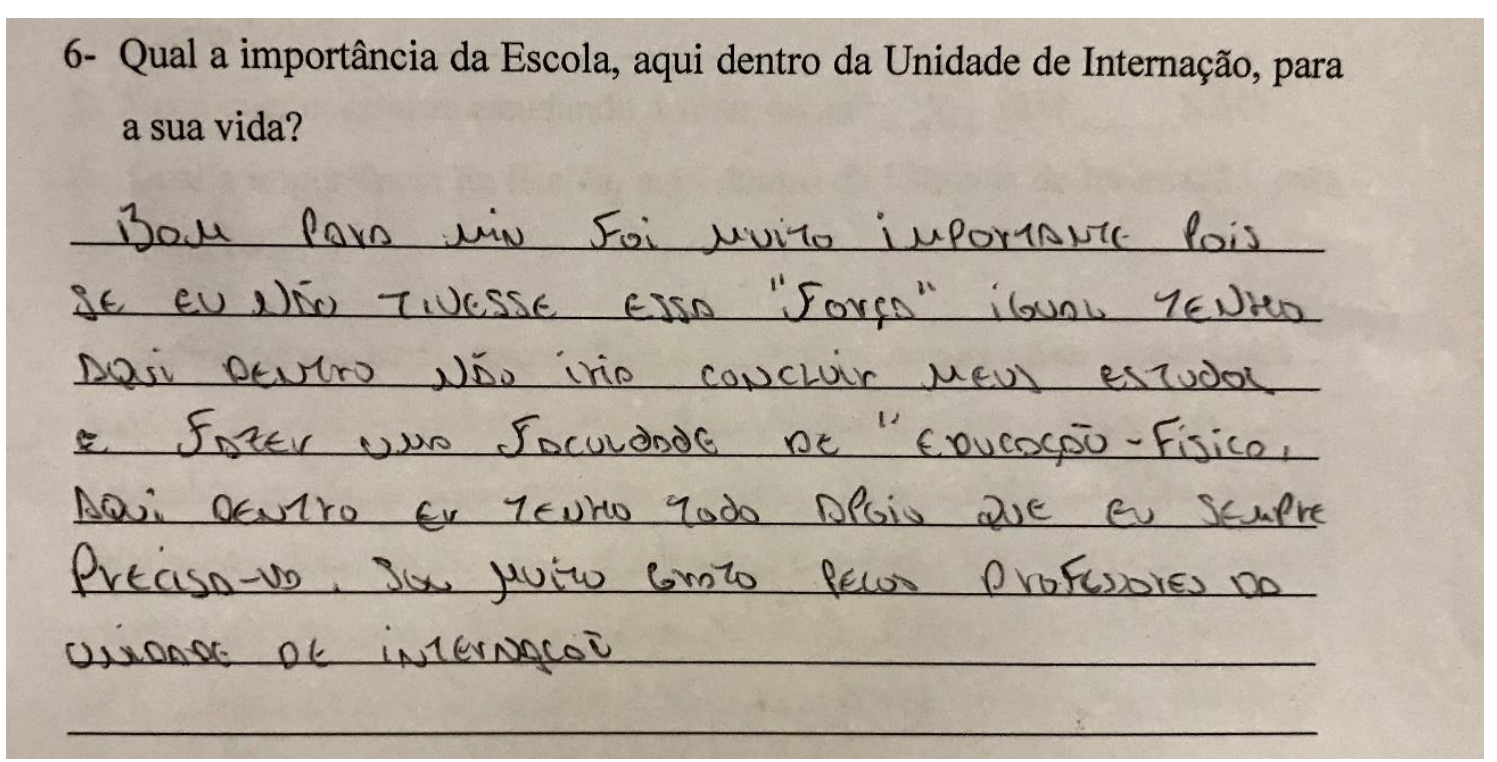

Fonte: a autora (2019)

Durante o tempo que estivemos na UISS foi possível observar que há uma carência muito significativa provinda dos internos no que diz respeito a atenção, afetividade, moralidade, valores sociais e outros aspectos. Portanto, no relato em questão, essa observação pôde ser comprovada quando o autor afirmou que "aqui dentro eu tenho o apoio que eu sempre precisava. ", pois entendemos que na sua vida fora do sistema socioeducativo, o mesmo não tinha incentivo e apoio para seguir outro rumo que não seja o do crime. $O$ agradecimento aos professores da unidade foi extremamente gratificante uma vez que, compreendido o papel do educador no contexto prisional, os desafios são muitos. Assim sendo, mais uma 
vez a contenção de um adolescente proporcionou uma nova concepção de vida, contribuindo para o sucesso de sua ressocialização.

Por meio de todos os relatos analisados, foi possível constatar que a Escola é vista como um refúgio para esses alunos, pois em meio à turbulência do contexto socioeducativo, a mesma é tida como um ambiente de calmaria, distração, liberdade de expressão e de ensinamentos relevantes para o incentivo à mudança de vida dos internos.

Quantos aos dados da Codeplan (2013), a pesquisa realizada por eles mostrou que 93\% dos socioeducandos acreditam que a Escola pode mudar a vida deles, porém, o percentual que obtivemos foi de $83 \%$ dos jovens que responderam o questionário disseram acreditar na Escola como um caminho para uma melhora na qualidade de vida. Analisando os valores, matematicamente é notória a diferença, tendo em vista a discrepância da quantidade de pessoas participantes. Todavia, ao olharmos para o viés da socioeducação, o resultado segue sendo excelente, pois são 83\% dos socioeducandos almejando não mais permanecerem na vida do crime e essa saída é viabilizada pelo contato deles com a Escola dentro das Uls. 


\section{CONCLUSÃO}

Durante o processo de construção deste trabalho, vivenciamos os constantes desafios que os professores enfrentam dentro do contexto da socioeducação. A realidade vivida por eles não é de conhecimento geral, assim como muitas das vezes os seus esforços não são valorizados. Portanto, por meio das observações realizadas foi possível coletar informações que trouxessem reconhecimento para essa prática docente.

Ainda com as observações, foi possível perceber que os educadores têm necessidade de adequarem-se ao sistema socioeducativo e, em inúmeras vezes, deixam os seus planejamentos de ensino de lado para suprirem as necessidades pessoais de seus alunos, como diálogos envolvendo valores morais, éticos e sociais, ou se disporem a ouvir um simples desabafo. Além de tudo, o histórico e contexto em que esses estudantes se encontram são muito particulares em diversos aspectos, portanto, cabe a Escola atender as especificidades de seus alunos, e aos seus envolvidos o discernimento de respeitarem as peculiaridades de cada interno durante o processo de escolarização. (DISTRITO FEDERAL, 2014).

É de se enaltecer o fato dos 35 voluntários terem colaborado com a causa maior dessa proposta, expondo-se ao relatarem suas experiências e opiniões em relação a Escola, os educadores e principalmente ao estabelecimento socioeducativo. Acreditamos que isso se deu devido ao bom relacionamento entre os professores e os alunos, o que resultou em uma confiança e credibilidade por parte dos socioeducandos para com o corpo docente e os pesquisadores envolvidos.

Visando a valorização dessa exposição por parte dos internos, confessamos que houve uma dificuldade na escolha de quais relatos seriam enfatizados no corpo deste trabalho, pois a grande maioria escreveu informações que muito contribuíram para o objetivo final, porém, alguns traziam ideias repetitivas ou informações sigilosas dos socioeducandos, não permitindo assim o seu uso. Contudo, optamos por selecionar alguns que não prejudicassem o voluntário e/ou a equipe da Unidade.

Com base nas experiências vividas no desenvolvimento deste projeto, nas observações feitas e nos relatos dos socioeducandos, concluimos que a Escola, 
dentro de uma Unidade de Internação, como a de São Sebastião, representa a oportunidade de se ter uma vida diferente da que os jovens estavam inseridos. $E$ ao se falar nessa mudança, a mesma refere-se não somente a maneira como esses meninos ganharão a vida após a liberação, mas a uma evolução social, psicológica e moral, uma vez que, assim como relatado, o convívio na Escola melhora também a sua maneira de se relacionar com o outro e os fazem refletirem sobre o seu comportamento na sociedade.

Considerando todas as concepções estudadas, entramos novamente em concordância com Volpi (1997) uma vez que o mesmo afirma que a contenção interna dos indivíduos não é em si a medida socioeducativa, mas sim a condição para que os mesmos "reflitam sobre as violações que praticaram e decidam sobre o seu futuro exercício de sua cidadania". Visto que mais da metade dos jovens participantes não tinha nenhum vínculo com o ambiente escolar antes de adentrarem em uma Unidade de Internação, e a partir do contato com a Escola inserida e seu capacitado corpo docente, os mesmos passaram a cogitar, e alguns até convenceram-se, em alterarem a sua conduta.

Por fim, embora o regime prisional do nosso país deixe a desejar em alguns aspectos, a bagagem adquirida em virtude do trabalho elaborado enriqueceu-me como futura professora, assim como minha visão de educação e principalmente a importância do seu papel para o desenvolvimento integral dos jovens em cumprimento de medida privativa de liberdade, seja no Distrito Federal ou em outros lugares. Desta maneira, reforço que o Ensino dentro dos estabelecimentos de medidas socioeducativas deve continuar pois é por meio deste que a ressocialização desses indivíduos dar-se-á. 


\section{REFERÊNCIAS BIBLIOGRÁFICAS}

BRASIL. CONANDA. Resolução № 119, 2006. Disponível em: $<$ https://www.legisweb.com.br/legislacao/?id=104396 > acesso em 10 de jul. de 2019.

BRASIL. Constituição (1988). Constituição da República Federativa do Brasil: texto constitucional promulgado em 5 de outubro de 1988, com as alterações determinadas pelas Emendas Constitucionais de Revisão nos 1 a 6/94, pelas Emendas Constitucionais nos 1/92 a 91/2016 e pelo Decreto Legislativo no 186/2008. - Brasília: Senado Federal, Coordenação de Edições Técnicas, 2016. Disponível em: $<$ https://www2.senado.leg.br/bds//bitstream/handle/id/518231/CF88 Livro EC91 2016.pdf> acesso em 1 de nov. de 2018

BRASIL. Estatuto da Criança e do Adolescente. Lei o 8.069/1990. $2^{\text {a }}$ ed. rev., atual. e ampl. Brasília: Senado Federal, 1997. Disponível em: $<$ http://www.planalto.gov.br/ccivil 03/leis//8069.htm> acesso em 1 de nov. de 2018

BRASIL. Presidência da República. Estatuto da Juventude. Lei oㅜ 12.852/2013. Brasília, 2013. Disponível em: <http://www.planalto.gov.br/ccivil 03/ ato20112014/2013/lei/l12852.htm> acesso em: 19 de jun. de 2019

BRASIL. Lei de diretrizes e bases da educação nacional- LDB. Lei № 9.394. Brasília, 1996. Edição atualizada até março de 2017. Disponível em: $<$ http://www2.senado.leg.br/bdsf/bitstream/handle/id/529732/lei de diretrizes e b ases 1ed.pdf > acesso em: 1 de nov. de 2018

BRASIL. Presidência da República. Sistema Nacional de Atendimento Socioeducativo - SINASE. Lei no 12.594/2012. Disponível em: <http://www.planalto.gov.br/ccivil_03/_Ato2011-2014/2012/Lei/L12594.htm> acesso em: 6 de dez. de 2018 
CONANDA. Sistema Nacional de Atendimento Socioeducativo - SINASE Brasília: CONANDA, 2006. Disponível em: < http://www.conselhodacrianca.al.gov.br/sala-de-imprensa/publicacoes/sinase.pdf> acesso em 9 de jul. de 2019.

DISTRITO FEDERAL. CODEPLAN. Perfil e Percepção Social dos Adolescentes em Medida Socioeducativa no Distrito Federal. Brasília, 2013.

DISTRITO FEDERAL. Diretrizes Pedagógicas Escolarização na Socioeducação. Secretaria de Estado de Educação do Distrito Federal - GDF. Brasília, 2014.

FREIRE, Paulo. Pedagogia da Autonomia: saberes necessários à pratica educativa. 56ํe ed. Rio de Janeiro/São Paulo: Paz e Terra, 2018.

LARROSA, Jorge. Experiência e Alteridade em educação. Revista Reflexão e Ação, Santa Cruz do Sul, v.19, n2, p.04-27, jul./dez. 2011.

NOGUEIRA, Roberto. Elaboração e análise de questionários: uma revisão da literatura básica e a aplicação dos conceitos a um caso real. Rio de Janeiro: UFRJ/COPPEAD, $2002 . \quad$ Disponível em: $<$ https://www.coppead.ufri.br/upload/publicacoes/350.pdf $>$ acesso em: $10 \mathrm{de}$ dez. de 2018

SANTOS, Luiz Pereira dos. MALDANER, Otavio Aloisio. Ensino de Química em Foco. Ed. Unijui, 2015.

SAVIANI, Dermeval. Escola e Democracia. Edição Comemorativa. Campinas: Autores Associados, 2008.

SILVA, Clawdemmy Feitosa E. A Socioeducação e Direitos Humanos: Um Estudo do Projeto “A Arte do Saber". Orientador Regina Lucia Sucupira Pedroza. Brasília, 2017. 172p. 
STÉFANO, Vanessa Carla. Conceitos básicos da Socioeducação na Formação do Profissional do Sistema Nacional de Atendimento Socioeducativo (SINASE). Um estudo exploratório do curso virtual núcleo básico da Escola Nacional de Socioeducação (ENS). Brasília, 2017. (Trabalho de Conclusão de Curso UnB)

VOLPI, Mário. O adolescente e o ato infracional. São Paulo: Cortez, 1997.

WOICOLESCO, Vanessa Gabrielle. Uma Análise da Educação Escolar Dos Adolescentes Privados de Liberdade Em Foz do Iguaçu - Paraná. Foz do Iguaçu: UNIOESTE, 2009 (Apresentação de Trabalho/comunicação). Disponível em: $<$ https://docplayer.com.br/77785021-Uma-analise-da-educacao-escolar-dosadolescentes-privados-de-liberdade-em-foz-do-iguacu-parana.html> acesso em 19 de jun. de 2019.

ZANELLI, J. C. Pesquisa qualitativa em estudos da gestão de pessoas. Estudos de Psicologia, v. 7, p. 79 - 88, 2002. 
APÊNDICES 


\section{Questionário}

Agindo com sinceridade...

1- Qual a sua idade?

ANOS

2- Você tem filho (a) (s)? SIM $\mathrm{NÃO}$, se sim, quantos?

3- Você estudava antes de vir para a Unidade? SIM NÃO

4- Se você respondeu sim na pergunta 3, qual a série na qual estava matriculado?

5- Você quer continuar estudando ao sair daqui? SIM NÃO

6- Qual a importância da Escola, aqui dentro da Unidade de Internação, para a sua vida? 
ANEXOS 